\title{
Attitude of Secondary Student-Teachers under Jurisdiction of Bangalore University towards Teaching Practice
}

\author{
Mr. Prasadappa. Y. $N^{1 *}$, Dr. M.S. Talawar ${ }^{2}$
}

\section{ABSTRACT}

Teaching practice occupies a key position in the programme of teacher education. It is the practical use of teaching methods, strategies, principles, techniques and practical training and practice or exercise of different activities of daily school life. Practice teaching sometimes becomes a demoralizing and sometimes very frightening experience for the student teachers. In this context this study was identifies both positive and negative attitude of student teachers during practice teaching and based on the finding of this study, measures were suggested on how to improve practice teaching.

Keywords: Attitude, Teaching Practice, Trainee Teachers.

Education is one of the most powerful instruments for development. It is the key to progress and development for the human species, its interface with sustainable development in all human society today cannot be over emphasized. Developing countries face barrage of extraordinary problem among which are abject mass poverty, superstition, sanitation, illiteracy, corruption etc. The solution of course, lies in proper education of the masses. Thus education according to Nelson Mandela it is most powerful weapon which you can use to change the world. It is key to reducing poverty, to creating sustainable planet. Okafor (1991) speaking about the secret of America's power, pointed out that America built her greatness in the classroom. Developing country India in particular should emulate this.

The role of the teacher in sustainable development cannot be quantified, especially in training personnel in various areas of the workforce. however ,the teacher needs to be properly educated and trained for professional efficiency and inculcated with a positive attitude that will enable teacher go through the training properly and come out well equipped for the responsibility ahead. Many countries have solved many of their problems through education and the secret lay

\footnotetext{
${ }^{1}$ Research Scholar, Department of Education, Bangalore University, Jnanabharathi, Bengaluru, India

${ }^{2}$ Research Guide, Department of Education, Bangalore University, Jnanabharathi, Bengaluru, India

*Responding Author
}

Received: December 27, 2016; Revision Received: January 18, 2017; Accepted: January 27, 2017

(C) 2017 Prasadappa N, Talawar M; licensee IJIP. This is an Open Access Research distributed under the terms of the Creative Commons Attribution License (www.creativecommons.org/licenses/by/2.0), which permits unrestricted use, distribution, and reproduction in any Medium, provided the original work is properly cited. 


\section{Attitude of Secondary Student-Teachers under Jurisdiction of Bangalore University towards Teaching Practice}

in effective classroom activities. Today the secret of America's greatness emerged from the classroom. Professors place high premium on teaching practice because it enables the students' practicalize all the theoretical teachings on the educations principles and practice. Taneja (2000) pointed out that number of term ,such as the practice teaching, field studies, infield experience, school based experience or internship are used. In view of this, teaching practice occupies a key position in the programme of teacher education and also it is common professional element in preparation of teachers. It is the first official opportunity for trainee teacher to involve in actual teaching experience. Ashraf (1999) noted that the term teaching practice embraces all the learning experience of student teachers in schools. Marais and Meier (2004) pointed that the term practice teaching represents the range of experiences to which student- teachers are exposed whom they work in classrooms and schools.

Teaching practice is an important component of becoming a teacher. It grants student teachers experience in the actual teaching and learning environment. Teaching practice is the name of the preparation of student teachers for teaching by practical training. It is the practical use of teaching methods, teaching strategies, teaching principles, teaching techniques and practical training and practice or exercise of different activities of daily school life. One of the main objectives of teaching practice, as Salzillo and Van Fleet (1977-28) point out is that encouraging an appropriate professional socialization process for the future teacher. However despite its importance, Killen and Steyn (2001) note that teaching practice sometimes becomes a demoralizing and sometimes very frightening experience for the student teachers?

Several studies have been conducted on student teacher's experience and anxieties during teaching practice (Ngidi and Sibaya 2003, marais of meier 2004) to mention but two. However a review of the literature indicates that there are limited studies that have been conducted regarding ways in which students experience during teaching practice influence their perception of and attitudes towards teaching practice. In this study identifies both the positive and negative experience of student teachers during teaching practice and based in the finding of this study, measures were suggested on how to improve practice teaching.

\section{Statement of the problem}

The problem chosen for the study may be stated as "Attitude of Student-Teachers towards Teaching Practice in the Bangalore University"

\section{Objectives of the Study}

The objectives of this study is to ascertain the attitude of the students in colleges of Education in Bangalore University towards teaching practice as an impetus for their professionalization. Specifically, the study sought to:

1. Determine the attitude of the student teachers towards teaching practice. 


\section{Attitude of Secondary Student-Teachers under Jurisdiction of Bangalore University towards Teaching Practice}

2. Identify the problems facing practical teaching and it's related activities in Bangalore university.

3. Identify strategies for improvement in the attitude of the student teachers.

\section{Research Questions}

1. What is the attitude of the student teachers towards teaching practice?

2. What are the problems facing practical teaching and its related activities in Bangalore university?

3. What are the strategies for improving the attitude of student teachers towards teaching practice?

\section{RESEARCH METHODOLOGY}

\section{Design of the study}

The design of the study is a descriptive survey which attempts to collect data from members of a population in order to determine the current status of the population.

\section{Are of the Study}

The study was carried out in colleges of education in Bangalore university

\section{Population of Study}

The target population comprised of all the students in secondary teacher education level in Bangalore University who were on teaching practice, all the principals and teachers of the school used for teaching practice.

\section{Sample and Sampling Techniques}

The sample were selected through Simple balloting was used to choose 50 students from each of the three colleges of education who were on teaching practice, 10 principals and 20 teachers of the schools used for teaching practice. The total sample used for the study was 180.

\section{Tools for Data Collection}

The student Teachers and Teaching Practice (STTP) attitude scale designed and standardized by A.U.NwanekeZi, N.J. Okali and Sam.A.Mezieobi's has been used in the research study for the collection of the data. The tool was face validated by two experts in Education Science and Education Foundation. The reliability of 0.87 (87\%) was calculated using Cronbach Alpha technique. This value was deemed appropriate for the study.

\section{Method of Data Analysis}

Descriptive data analysis (mean and decision) were used to answer the research questions. A mean of 2.50 and above indicates agreement with the item statement while a mean of 2.49 and

(c) The International Journal of Indian Psychology, ISSN 2348-5396 (e)| ISSN: 2349-3429 (p) | 159 
below indicate disagreement. For ease of analysis of the research question 1, a mean of 2.50 and above was regarded as positive attitude while 2.49 and below was regarded as negative attitude. In research question 2 and 3, a mean of 2.50 was taken as "agree" 2.49 and below as "disagree".

\section{RESULTS AND DISCUSSION}

The results were presented in line with the research questions

Table 1 (a): Mean Ratings of the 300 and 200 Level Student Teachers on Their Attitude towards Teaching Practice

\begin{tabular}{|l|l|l|}
\hline S/No & $\begin{array}{l}\text { Items on the Attitude of Student Teachers Towards } \\
\text { Teaching Practice }\end{array}$ & $\begin{array}{l}\text { Secondary level T/P } \\
\text { students }\end{array}$ \\
\hline 1 & $\begin{array}{l}\text { Teaching practice is very good experience and should be } \\
\text { allowed to continue }\end{array}$ & 3.58 positive \\
\hline 2 & $\begin{array}{l}\text { Teaching practice is a fun and should be extended to 6 months. } \\
\text { I have never been absent from my school location since I was } \\
\text { posted }\end{array}$ & 3.27 positive \\
\hline 3 & I am always regular to school & 3.48 positive \\
\hline 4 & $\begin{array}{l}\text { I am always there at my school location whether I have period } \\
\text { to teach or not }\end{array}$ & 3.38 positive \\
\hline 6 & I am always ready with my lesson notes & 3.43 positive \\
\hline 7 & $\begin{array}{l}\text { I like to teach my lesson than watching the regular teacher use } \\
\text { my period }\end{array}$ & 3.22 positive \\
\hline 8 & I prefer being supervised by my teachers & 3.32 positive \\
\hline 9 & $\begin{array}{l}\text { I have mutual understanding with my students and the school } \\
\text { authority }\end{array}$ & 3.27 positive \\
\hline 10 & I teach all my lessons with instructional materials & 3.46 positive \\
\hline
\end{tabular}

In table 1 , the mean ratings of the secondary teacher education level students show that the respondents scored up to 2.50 and above showing that the y have positive attitude in all the listed items.

Table 1 (b): Mean rating on the observed attitude of the secondary teacher education level students towards Teaching Practice by the Practicing Schools

\begin{tabular}{|l|l|l|l|}
\hline S/No & $\begin{array}{l}\text { Observed attitude of the students towards } \\
\text { Teaching Practice }\end{array}$ & \multicolumn{2}{l|}{} \\
\hline & $\begin{array}{l}\text { The following attitude were observed in the } \\
\text { students during Teaching Practice }\end{array}$ & Principal & Teachers \\
\hline 11 & Prompt report to the school location & $\mathbf{2 . 2 2}$ Negative & 2.00 Negative \\
\hline 12 & Diligent to duty & 3.27 positive & 3.12 positive \\
\hline 13 & Regularity to school & 3.46 positive & 3.23 positive \\
\hline 14 & Punctuality to school & $\mathbf{2 . 4 4}$ Negative & $\mathbf{2 . 0 2}$ Negative \\
\hline 15 & Resourceful & $\mathbf{2 . 3 5}$ Negative & $\mathbf{2 . 2 9}$ Negative \\
\hline 16 & Good relationship with teachers and students & 3.48 positive & 2.70 positive \\
\hline
\end{tabular}

(c) The International Journal of Indian Psychology, ISSN 2348-5396 (e)| ISSN: 2349-3429 (p) | 160 
Attitude of Secondary Student-Teachers under Jurisdiction of Bangalore University towards Teaching Practice

\begin{tabular}{|l|l|l|l|}
\hline S/No & $\begin{array}{l}\text { Observed attitude of the students towards } \\
\text { Teaching Practice }\end{array}$ & \multicolumn{2}{|l|}{} \\
\hline 17 & Obedient/respect to school authority & 3.48 positive & 3.67 positive \\
\hline 18 & Readiness to take instruction/corrections & 3.26 positive & 3.30 positive \\
\hline 19 & Decency in dressing & 3.36 positive & 3.10 positive \\
\hline 20 & Ability to teach & $\mathbf{2 . 1 1}$ Negative & $\mathbf{2 . 2 4}$ Negative \\
\hline
\end{tabular}

Table 1 (a) reveals that the mean ratings of the students showed that the respondents scored up to 2.50 and above (Table 1 (b)) showing that they have positive attitudes in all the listed items except in 15 and 20 where the principals and teachers scored below acceptable mean (2.35 and $2.29)$ and (2.11-2.24) respectively.

Table 2: Mean Ratings on the Problems Facing Teaching Practice in the Bangalore University

\begin{tabular}{|c|c|c|}
\hline S/No & Items on the problem facing teaching practice & $\begin{array}{l}\text { Secondary level } \\
\text { T/P students }\end{array}$ \\
\hline & $\begin{array}{l}\text { The following are the problems facing teaching practice in } \\
\text { University of Bangalore }\end{array}$ & \\
\hline 21 & Inadequate preparation of students for teaching practice & 2.71 Agree \\
\hline 22 & $\begin{array}{l}\text { Lack of necessary equipment, facilities and materials for preparation } \\
\text { of the students before sending them out for teaching practice }\end{array}$ & 2.50 Agree \\
\hline 23 & Unwillingness of the students to report to their school locations & 2.37 Disagree \\
\hline 24 & Few number of practicing schools within Bangalore & 2.67 Agree \\
\hline 25 & $\begin{array}{l}\text { Poor learning environment in the practicing schools, such as class } \\
\text { congestion, poor ventilation, poor facilities and equipment }\end{array}$ & 2.60 Agree \\
\hline 26 & $\begin{array}{l}\text { Lack of accommodation for the student teachers especially those } \\
\text { posted very far from the colleges of education. }\end{array}$ & 2.49 Disagree \\
\hline 27 & Short practicing period & 2.90 Agree \\
\hline 28 & Rejection of students by some schools & 2.64 Agree \\
\hline 29 & Lack of transportation fare on the part of the student teachers & 2.61 Agree \\
\hline 30 & Inaccessibility of some school locations by students and lecturers & 2.65 Agree \\
\hline
\end{tabular}

Table 2 reveals that the mean ratings of the student's shows that the respondents scored up to 2.50 and above, showing that all the respondents agreed that all the listed items are the problems facing teaching practice.

Table 3: Rating on Strategies for Improving Students Attitude towards Teaching Practice

\begin{tabular}{|l|l|l|}
\hline s/no & $\begin{array}{l}\text { Items strategies to improve the attitude of the students towards } \\
\text { teaching practice }\end{array}$ & $\begin{array}{l}\text { Secondary } \\
\text { level } \\
\text { students }\end{array}$ \\
\hline & $\begin{array}{l}\text { The following strategies should improve the attitude of the students } \\
\text { towards teaching practice }\end{array}$ & \\
\hline
\end{tabular}

(c) The International Journal of Indian Psychology, ISSN 2348-5396 (e)| ISSN: 2349-3429 (p) | 161 


\begin{tabular}{|l|l|l|}
\hline s/no & $\begin{array}{l}\text { Items strategies to improve the attitude of the students towards } \\
\text { teaching practice }\end{array}$ & $\begin{array}{l}\text { Secondary } \\
\text { level } \\
\text { students }\end{array}$ \\
\hline 31 & \begin{tabular}{l} 
Students should be well prepared before posting to schools \\
\hline 32
\end{tabular} & $\begin{array}{l}\text { Micro-teaching laboratory should be put in place and be used to } \\
\text { groom the students well enough before posting to schools }\end{array}$ \\
\hline 33 & $\begin{array}{l}\text { As much as possible students should be sent to good schools, } \\
\text { considering the accessibility and nearness to the college/institution }\end{array}$ & 3.19 \\
\hline 34 & $\begin{array}{l}\text { College/Institution should give each practicing students some } \\
\text { financial support for their upkeep during the period of teaching } \\
\text { practice }\end{array}$ & $\mathbf{2 . 1 9}$ \\
\hline 35 & $\begin{array}{l}\text { The college/institution buses should be used to convey the students to } \\
\text { their various school locations }\end{array}$ & 3.04 \\
\hline 36 & $\begin{array}{l}\text { The school authority should liaise with far school locations to arrange } \\
\text { accommodation for the students }\end{array}$ & 2.96 \\
\hline 37 & $\begin{array}{l}\text { Lecturers should not collect gifts either in form of money or materials } \\
\text { from the students }\end{array}$ & 3.08 \\
\hline 38 & $\begin{array}{l}\text { Lecturers should inform the students when they want to visit each } \\
\text { school for supervision }\end{array}$ & 2.72 \\
\hline 39 & Teaching practice handbook should be made available to students & $\mathbf{2 . 1 0}$ \\
\hline 40 & Students should be briefed before reporting to their school locations & 3.16 \\
\hline
\end{tabular}

Table 3 reveals that the mean responses of the secondary teacher education level students reached to the acceptable mean of 2.50 and above. This is an indication that all the designated strategies should be adopted for improvement in the attitude of the students on teaching.

\section{DISCUSSION OF THE FINDINGS}

In the table 1, the mean ratings of the respondents secondary teacher education level students, the principals and teachers indicated generally that the students have positive attitude towards teaching practice except that some would not report promptly to their school locations and sometimes they would not be punctual to school. and also sometimes they would not resourceful in ability to teach in school. This might be due to inaccessibility of some school locations, far distance and sometimes traffic congestion in town and also teaching aid due to inaccessibility of some colleges of education and schools.

In Table 2, the mean ratings of the secondary teacher education level students indicated agreement that all the listed items are problem facing teaching practice in the Bangalore University.

In response to research question 3, the respondents agreed that all the stipulated strategies would be adopted to ensure positive attitude by the students towards teaching practice. This shows that the students are unanimous in their mean ratings. One could therefore conclude that if all the

(c) The International Journal of Indian Psychology, ISSN 2348-5396 (e)| ISSN: 2349-3429 (p) | 162 


\section{Attitude of Secondary Student-Teachers under Jurisdiction of Bangalore University towards Teaching Practice}

stated strategies would be adopted, no doubt, the student's attitude towards teaching practice will be affected positively.

\section{CONCLUSION}

The attainment of quality education will be a mirage without adequate preparation of manpower who will dispense the knowledge. This calls for serious consideration of stipulated strategies to be adopted.

\section{RECOMMENDATIONS}

In order to build positive attitude of students towards teaching practice in Bangalore University, we recommended as follows:

1. Colleges of Education should have a micro-teaching laboratory where students will be well exposed to the rudiments of teaching.

2. There should be teaching practice handbook for the students to have a uniform method of writing lesson notes. Rules and regulations of practical teaching will also be stipulated in this hand book.

3. Students should be sent to good schools with suitable learning environment.

4. The school location should be accessible both for lecturers and students.

5. Secondary Teacher Education Institutions shall collaborate with corporate sector in teaching practice programme so as to seek financial support for the said programme.

\section{Acknowledgments}

The author appreciates all those who participated in the study and helped to facilitate the research process.

\section{Conflict of Interests}

The author declared no conflict of interests.

\section{REFERENCES}

Akbar, R.A. (2002). A study of Practice Teaching of Prospective Secondary School Teachers and Development of a Practice Teaching Model, Arid Agricultural University. Rawalpindi (Unpublished PhD Thesis).

Allen, D.W., \& Eve, A.W. (1968). Microteaching. Theory into practice, 7(5), 181-185.

Balamohandas, V. and Sharma, M.(2012). Quality Teachers: A must for Quality Higher Education. University News. Vol. 50 No. 03, p.6-10

Cohen,a. \& Carver, N. (1970). A Student's Guide to Teaching Practice. University of London Press, London.

Furlong, V.J.; P.U. Hirst and K. Pocklington. (1988). Initial Teacher Training and The Role of the School. Open University Press, Philadelphia.

(C) The International Journal of Indian Psychology, ISSN 2348-5396 (e) | ISSN: 2349-3429 (p) | 163 


\section{Attitude of Secondary Student-Teachers under Jurisdiction of Bangalore University towards Teaching Practice}

George, A.C. (2004). A manual of practice teaching. New Delhi: Commonwealth Publishers Jangira, N.K.,\& Singh, A. (1982). Core Teaching Skills: Micro Teaching Approach. New Delhi, NCERT. (Unit 2: Strengthening Student Teaching, p 9-18)

K. Natesh and et. Al. (2010). Quality concerns in Teacher Education. New Delhi: APH Publishing Corporation

Mohanty, S.B. (2010). A Review of National Curriculum Framework for Teacher Education: Towards Preparing Profssional and Humane Teacher. Journal of AIAER 22(1)

NCTE (1998). Curriculum framework for Quality Teacher Education. New Delhi: NCTE

NCTE (2009). National Curriculum framework for Teacher Education. New Delhi: NCTE Singh, L.C. (Ed.) (1999). Teacher Education in India-A Resource Book. New Delhi: NCERT Taneja, R.P. (2000). Encyclopedia of Comparative Education, Vol.4. Anmol Publications Pvt. Ltd., New Delhi.

How to cite this article: Prasadappa N, Talawar M (2017), Attitude of Secondary StudentTeachers under Jurisdiction of Bangalore University towards Teaching Practice, International Journal of Indian Psychology, Volume 4, Issue 2, No. 85, ISSN:2348-5396 (e), ISSN:2349-3429 (p), DIP:18.01.019/20170402, ISBN: 978-1-365-68608-5

(c) The International Journal of Indian Psychology, ISSN 2348-5396 (e)| ISSN: 2349-3429 (p) | 164 